Q. BI, ${ }^{1}$ J.-Yu LI, ${ }^{2}$ X.-Q. LI, ${ }^{1}$ Q. LI, ${ }^{3}$ D. LUO, ${ }^{1}$ and Q.-B. QIAO ${ }^{4}$

\title{
IMPACT OF INTRACRANIAL ARTERY DISEASE AND PRIOR CEREBRAL INFARCTION ON CENTRAL NERVOUS SYSTEM COMPLICATIONS AFTER OFF-PUMP CORONARY ARTERY BYPASS GRAFTING
}

\begin{abstract}
Received 01.07.13
We tried to determine whether postoperative CNS complications after off-pump coronary artery bypass grafting (OPCABG) are related to prior cerebral infarction or intracranial artery disease. Fifty-five patients (40 men, mean age $64.59 \pm 8.86$ years) subjected to OPCABG underwent neurological and neuropsychological examinations $24 \mathrm{~h}$ before surgery. MRI was used to identify old and/or new ischemic lesions before surgery, and MRA was used to determine the presence and severity of intracranial artery disease. The patients were examined eight days after surgery; possible development of stroke or cognitive dysfunction was evaluated. Associations between postoperative stroke and potential predictors, including prior cerebral infarction and intracranial artery disease, were analyzed using univariate methods. Two of $55(3.64 \%)$ patients had postoperative stroke, and no patient showed cognitive decline. Univariate analysis found no significant association between postoperative stroke and prior cerebral infarction detected by MRI $(P=0.378)$ or intracranial artery disease detected by MRA $(P=0.103)$. Our results suggest that intracranial artery disease and prior cerebral infarction are not independent risk factors for stroke after OPCABG. Nonetheless, further investigation of these associations is necessary.
\end{abstract}

Keywords: off-pump coronary artery bypass grafting, prior cerebral infarction, intracranial artery disease, stroke.

\section{INTRODUCTION}

Devastating CNS complications, including stroke, can occur following coronary artery bypass grafting $(\mathrm{CABG})$, with an incidence of $2.6-7.6 \%[1,2]$. Cognitive dysfunction (with an incidence of 30-65\%) $[3,4]$, anxiety, and depression are also among such complications. These complications significantly increase disability and mortality of the patients, as well as healthcare costs $[5,6]$. A number of risk factors can contribute to the occurrence of CNS complications

\footnotetext{
${ }^{1}$ Department of Neurology, Beijing Anzhen Hospital, Capital Medical University, Beijing, China.

${ }^{2}$ Emergency Department of Beijing Charity Hospital, China Rehabilitation Research Center, Capital Medical University School of Rehabilitation Medicine, Beijing, China.

${ }^{3}$ Department of Cardiac Surgery, Beijing Anzhen Hospital, Capital Medical University, Beijing, China.

${ }^{4}$ Department of Neurology, Xian Number Four Hospital, Xian, Shanxi Province, China.

Correspondence should be addressed to Q. Bi

(e-mail: biqidoctor@163.com).
}

after $\mathrm{CABG}$, including age, unstable angina, prior stroke or transient ischemic attacks, carotid bruits, carotid artery disease, left ventricular ejection fraction (LVEF) below 50\%, cardiopulmonary bypass, postoperative atrial fibrillation, and postoperative hypotension [6-9]. Intracranial artery disease is also an independent risk factor for CNS complications after CABG [10].

Postoperative CNS complications are thought to be due mainly to the adverse effect of cardiopulmonary bypass [11-13]. The incidence of stroke or cognitive dysfunctions does not decrease after off-pump coronary artery bypass grafting (OPCABG), although this method can avoid the adverse effects of extracorporal circulation [14]. Therefore, the risk factors for CNS complications after OPCABG must be re-examined. In our study, we prospectively studied patients undergoing OPCABG and tried to determine whether intracranial artery disease and prior cerebral infarction constitute potential risk factors for CNS complications. 


\section{METHODS}

Examined Group. A total of 55 consecutive patients scheduled for OPCABG at the Beijing Anzhen Hospital were believed eligible for inclusion in the study. Patients with significant pre-existing neurological deficits (according to Mini-Mental State Examination, MMSE [15] scores) that would hamper interpretation of the clinical and radiological data, scores of the National Institute of Heart Stroke Scale below 4 [16], and/or contraindications for MRI (such as the use of a cardiac pacemaker) were not included in the group.

Data Collection. The following potential risk factors for CNS complications after OPCABG were noted before surgery: history of stroke, hypertension, diabetes mellitus, hyperlipidemia, cardiac surgery, atrial fibrillation, smoking, and alcohol abuse. The MRI and MRA studies were performed before surgery. The MRI studies were repeated in patients with new symptoms of stroke after OPCABG to confirm the diagnosis of stroke. The results of MRI were examined by two imaging specialists to identify the presence of infarct foci. The intracranial arteries were examined to detect the presence of intracranial artery disease, defined as luminal narrowing exceeding 50\% [17]. Among them, there were the intracranial internal carotid artery, anterior, middle, and posterior cerebral arteries, intracranial vertebral artery, and basilar artery.

Assessment and Definition of CNS Complications. Neurological examinations of the patients' cognitive functions, level of anxiety, and depression states were performed before and eight days after surgery to detect the presence of CNS complications. All assessments were performed by an investigator blinded to the MRI and MRA results. The MMSE, Clinical Dementia Rating (CDR), and Global Deterioration Scale (GDS) were used to evaluate the state of cognitive functions. The Self-rating Anxiety Scale (SAS) and Self-rating Depression Scale (SDS) were used to assess the anxiety level and depression state.

The CNS complications were classified as stroke, mild cognitive impairment (MCI), depression, or abnormally high anxiety. Stroke was defined as a new focal neurological deficit lasting more than $24 \mathrm{~h}$ with an MRI finding consistent with a new ischemic injury. The diagnosis of MCI was made according to the following criteria: (i) memory complaint, (ii) normal activities in daily living, (iii) normal general cognitive function, (iv) memory abnormal for the patient's age, and (v) absence of dementia [18]. Depression and anxiety were defined as SDS and SAS index values (transformed from raw scores) below or equal to 50, respectively [19].

MRI and MRA. All MRI studies were performed with a 1.5-Tesla scanner Sonata (Siemens Healthcare, Germany); T1-weighted images, T2-weighted images, and diffusion-weighted images (DWIs) were acquired using a spin echo sequence, a turbo spin echo sequence, and an echo planar imaging sequence, respectively. Three-dimensional time-of-flight MRA (Sonata, Siemens Healthcare, Germany) was used to assess the presence of intracranial artery disease. Perfusionweighted imaging (PWI) results were processed with STROKETOOL software (Digital Image Solutions, Germany), supported by the Düsseldorf University Hospital. The regional cerebral blood volume (rCBV), regional cerebral blood flow (rCBF), mean transit time (MTT), and time to peak (TTP) were values calculated and analyzed.

Statistical Analysis. All data were analyzed using SPSS software (version 13.0; SPSS Inc., USA), with $P \leq 0.05$ considered indications of significant intergroup differences. Continuous variables were expressed as means \pm s.d., and categorical variables were expressed as numbers and frequencies. Univariate analysis was performed to determine differences in potential risk factors (including intracranial artery disease and prior stroke) between patients with and without CNS complications. Continuous variables were compared between groups using the $t$-test, and categorical variables were compared using the Fisher's exact test. Multivariate logistic regression was not estimated because of a relatively small sampling.

\section{RESULTS}

Fifty-five participants (40 men), mean age $64.59 \pm$ $\pm 8.86(45-84)$ years, were enrolled in the study (Table 1). All patients completed neurological and neuropsychological assessments at baseline and postoperative neurological assessments at a mean of $5 \pm$ \pm 3 days after surgery.

Two of the 55 patients $(3.64 \%)$ suffered from a clinically evident postoperative stroke and new ischemic lesions on postoperative DWIs. One of these patients (patient 1 in Table 2) experienced the sudden onset of incomplete motor aphasia and hemianopia five days after surgery, and large areas of new ischemic lesions dispersed within the right occipital lobe were found on the postoperative DWI. Another 
T a b l e 1. Baseline characteristics and outcomes of 55 patients undergoing off-pump coronary artery bypass grafting

Т а б л и ц я 1. Основні характеристики 55 паціснтів, яким проводили шунтування коронарної артерії без використання штучного кровообігу

\begin{tabular}{|c|c|c|c|c|}
\hline Item & $\begin{array}{c}\text { Total } \\
(n=55)\end{array}$ & $\begin{array}{l}\text { Stroke } \\
(n=2)\end{array}$ & $\begin{array}{l}\text { No stroke } \\
(n=53)\end{array}$ & $P$ \\
\hline Mean age, years & $64.85 \pm 8.72$ & $63.00 \pm 0.00$ & $64.92 \pm 8.88$ & 0.762 \\
\hline Stroke history & 10 & 0 & 10 & 0.667 \\
\hline Cardiac surgery history & 4 & 0 & 4 & 0.859 \\
\hline Atrial fibrillation & 4 & 0 & 4 & 0.859 \\
\hline Smoking & 27 & 1 & 26 & 0.745 \\
\hline Alcohol consumption & 16 & 1 & 15 & 0.525 \\
\hline Carotid artery stenosis & 13 & 1 & 12 & 0.449 \\
\hline $\begin{array}{l}\text { Left ventricular ejection fraction } \\
<40 \%\end{array}$ & 2 & 1 & 1 & 0.072 \\
\hline Infarction before surgery (MRI) & 34 & 2 & 32 & 0.378 \\
\hline $\begin{array}{l}\text { Intracranial artery disease before } \\
\text { surgery (MRA) }\end{array}$ & 18 & 2 & 16 & 0.103 \\
\hline
\end{tabular}

Footnotes: MRI is magnetic resonance imaging; MRA is magnetic resonance angiography. Asterisks shows preoperative assessment.

T a b l e 2. Clinical and radiological characteristics of the patients with postoperative stroke

Т а б л и ц я 2. Клінічні та радіологічні характеристики паціснтів із постопераційним інсультом

\begin{tabular}{|c|c|c|c|c|c|c|c|}
\hline Patient & \begin{tabular}{|c|}
$\begin{array}{c}\text { Age } \\
\text { (years) }\end{array}$ \\
\end{tabular} & Sex & Risk factors & Preop. MRI findings & Preop. MRA findings & Postop. MRI findings & $\begin{array}{c}\text { Clinical } \\
\text { manifestations }\end{array}$ \\
\hline 1 & 63 & Male & $\begin{array}{l}\text { HL, CAD, DM, } \\
\text { smoking, unilateral } \\
\text { carotid disease }\end{array}$ & $\begin{array}{l}\text { Prior cerebral } \\
\text { infarction }\end{array}$ & $\begin{array}{l}\text { Mild stenosis of the } \\
\text { left middle cerebral } \\
\text { artery }\end{array}$ & $\begin{array}{c}\text { Right occipital lobe } \\
\text { DWI }(+)\end{array}$ & $\begin{array}{l}\text { Motor aphasia, } \\
\text { hemianopia }\end{array}$ \\
\hline 2 & 63 & Male & $\begin{array}{l}\text { HL,CAD, DM, } \\
\text { HTN, LVEF }<40 \%\end{array}$ & $\begin{array}{l}\text { Prior cerebral } \\
\text { infarction }\end{array}$ & $\begin{array}{l}\text { Mild stenosis of the } \\
\text { bilateral posterior } \\
\text { cerebral arteries }\end{array}$ & $\begin{array}{l}\text { Right temporal } \\
\text { lobe, right basal } \\
\text { ganglia DWI }(+),\end{array}$ & $\begin{array}{l}\text { Paralysis and } \\
\text { numbness of the left } \\
\text { upper limb, aphasia }\end{array}$ \\
\hline
\end{tabular}

Footnotes: Preop., preoperative; Postop., postoperative; MRI, magnetic resonance imaging; MRA, magnetic resonance angiography; HL, high lipids; CAD, coronary artery disease; DM, diabetes mellitus; HTN, hypertension; LVEF, left ventricular ejection fraction; DWI, diffusion-weighted image.

patient (patient 2 in Table 2) experienced aphasia and paralysis + numbness of the left upper limb, with new lesions on the right temporal lobe and right basal ganglia detected on the postoperative DWI. These two patients were more than 60 years old and had histories of hyperlipidemia and diabetes mellitus, but these factors showed no significant difference from the rest of the patient sampling. Other variables, including risk factors for preoperative stroke, cardiac surgery history, and LVEF below $40 \%$, did not differ between patients with and without postoperative stroke (Table 3).

Preoperative MRI revealed subclinical (old) infarcts in the above two patients with postoperative stroke, but this finding did not differ significantly from those for their counterparts without postoperative stroke $(P=0.378)$. The MRA findings for intracranial artery disease also showed no difference between patients with and without postoperative stroke $(P=0.103$; 
T a b l e 3. Pre- and postoperative perfusion-weighted imaging findings

Т а б л и ц я 3. Пре- та постопераційні усереднені значення характеристик перфузії мозку

\begin{tabular}{|c|c|c|c|c|}
\hline Parameter & Preoperative & Postoperative & $t$ & $P$ \\
\hline \multicolumn{5}{|l|}{$\mathrm{rCBF}(\mathrm{ml} / 100 \mathrm{~g} / \mathrm{min})$} \\
\hline left hemisphere & $9.198 \pm 5.498$ & $9.045 \pm 3.979$ & 0.202 & 0.841 \\
\hline right hemisphere & $9.134 \pm 5.527$ & $9.173 \pm 4.247$ & -0.042 & 0.967 \\
\hline \multicolumn{5}{|l|}{$\mathrm{rCBV}(\mathrm{ml} / 100 \mathrm{~g})$ : } \\
\hline left hemisphere & $46.211 \pm 14.397$ & $44.641 \pm 16.036$ & 0.548 & 0.586 \\
\hline right hemisphere & $46.261 \pm 16.966$ & $45.852 \pm 16.419$ & 0.170 & 0.866 \\
\hline right hemisphere & $35.786 \pm 10.543$ & $35.686 \pm 10.421$ & 0.042 & 0.967 \\
\hline \multicolumn{5}{|l|}{ TTP(s): } \\
\hline left hemisphere & $37.839 \pm 4.952$ & $37.361 \pm 3.307$ & 0.713 & 0.480 \\
\hline right hemisphere & $38.064 \pm 5.033$ & $37.157 \pm 2.952$ & 1.312 & 0.196 \\
\hline
\end{tabular}

Footnotes: rCBF, regional cerebral blood flow; rCBV, regional cerebral blood volume; MTT, mean transit time; TTP, time to peak.

T a b l e 4. Neuropsychological characteristics of the patients before and after cardiac surgery

Т а б л и ц я 4. Нейропсихологічні характеристики пацієнтів перед операцією на серці та після неї

\begin{tabular}{|c|c|c|c|c|}
\hline & Preoperative & Postoperative & $t$ & $P$ \\
\hline Mini-Mental State Examination & $28.45 \pm 1.89$ & $28.34 \pm 2.53$ & 0.515 & 0.352 \\
\hline Clinical Dementia Rating & $0.16 \pm 0.27$ & $0.17 \pm 0.28$ & -1.000 & 0.322 \\
\hline Global Deterioration Scale & $1.23 \pm 0.42$ & $1.23 \pm 0.42$ & & \\
\hline
\end{tabular}

Table 3). Patient 1 had mild stenosis of the left middle cerebral artery that was not related to new infarction. Patient 2 had mild stenosis of the bilateral posterior cerebral arteries that was responsible for new ischemic lesions (Table 2). No significant difference was found in pre- and postoperative $\mathrm{rCBF}, \mathrm{rCBV}$, MTT, or TTP values on functional MRI for all 55 patients $(P>0.05$; Table 3).

No patient showed a decline in the neuropsychological measures (Table 4); changes in MMSE $(P=0.352)$ and $\operatorname{CDR}(P=0.322)$ scores were insignificant. Pre- and postoperative GDS scores did not differ from each other, and estimates of the psychomotor speed, mental flexibility, and memory tests were generally similar. Seven participants had mildly increased anxiety, and one patient suffered from mild depression, as determined by the preoperative administration of the SAS and SDS. Anxiety levels declined in two patients after surgery, but these changes in the anxiety level and depression were, in general, insignificant.

\section{DISCUSSION}

Cerebral injury is a devastating complication of CABG; globally, stroke occurs in $1.5-7.6 \%$ of the patients, encephalopathy affects $8.4-32 \%$ of those, and cognitive dysfunction affects $20-65 \%$ of the patients at discharge $[1-4,20]$. Variation in the incidences reported by different studies is likely due to differences in the patient samplings (e.g., patient age and risk status, types of procedures), diagnostic definitions, and intensity of clinical surveillance. The results of our study confirmed that neurological injury is relatively common after cardiac surgery, with approximately $4 \%$ of the patients experiencing postoperative stroke.

In previous studies $[6,8,9,21]$, the causative mechanisms and risk factors for perioperative strokes in patients undergoing CABG were determined. The incidence of postoperative stroke correlates mainly with the adverse effect of cardiopulmonary bypass due to large numbers of microemboli built by fragments of atheromatous plaques from the ascending 
aorta, thrombi, platelets, destroyed red blood cells, white blood cells, lipids, and gas [11, 13, 22]. Although OPCABG can avoid the adverse effects of extracorporeal circulation, a noticeable proportion of the patients still suffer from postoperative stroke [14].

In many studies, the relationship between carotid artery disease and risk of stroke after OPCABG was evaluated, although this correlation remains controversial [2, 23]. A few studies have examined the effect of intracranial artery disease on stroke after CABG. Yoon et al. [10] found that intracranial artery disease was associated independently with the development of CNS complications after CABG (prevalence odds ratio, 2.28, with a 1.04-5.01 confidence interval, after controlling for covariates, including age, occurrence of intraoperative events, and reoperation). Cheng-Ching et al. [24] also found that intracranial atherosclerosis may be an under-reported mechanism of perioperative stroke after open-heart surgery. However, only few studies have systematically investigated the role of intracranial artery disease as a risk factor for postoperative stroke in patients undergoing OPCABG. It was found that a history of stroke is an independent risk factor for postoperative stroke after CABG [25]. At the same time, single studies have investigated the relationship between prior ischemic lesions, including subclinical cerebral infarction, and postoperative stroke following OPCABG. In our study, the two patients who suffered from postoperative stroke had intracranial artery disease and ischemic lesions on preoperative MRI. Although prior cerebral infarction and intracranial artery disease appeared to be more prevalent in patients who experienced postoperative stroke than in those who did not, this difference was not found to be significant in our study, probably due in part to a small sampling size. Further studies are required to better understand the predictive values of intracranial artery disease and prior cerebral infarction for postoperative stroke.

Atherosclerosis is a systemic process, and risk factors for coronary artery disease can also affect the intracranial arteries. Coronary artery disease is prevalent in patients with stroke, including subclinical forms of the latter. Yoon et al. [10] found that $16.4 \%$ of the patients undergoing non-emergency isolated CABG had intracranial artery disease alone, and $13.9 \%$ had extra- and intracranial artery disease. Ito et al. [26] found that almost half (49.9\%) of the patients who underwent CABG had silent $(35.2 \%)$ or symptomatic (14.7\%) brain infarction. In our study, brain MRI with DWI and MRA findings revealed that $61.8 \%$ of the patients who underwent OPCABG had prior cerebral infarction, and $32.7 \%$ had intracranial artery disease. Considering the high incidence of prior cerebral infarction and intracranial artery disease in patients undergoing OPCABG, these patients should be identified for these conditions before surgery.

The cognitive decline was reported to occur in 30 $70 \%$ of the patients in the first week after cardiac surgery; this incidence declines to $30-50 \%$ at three weeks after surgery and may persist for one year [27, 28]. However, the incidence of postoperative cognitive impairment remains controversial and varies greatly depending on the patient's characteristics, the tests used to evaluate cognitive function, definitions of cognitive impairment, and the duration of follow up. No patient in our study showed severe cognitive impairment. Several explanations account for the discrepancies among the described results. Our study included only patients undergoing OPCABG, which is less likely than onpump CABG to result in CNS complications. The small sample size may also influence the results.

A reliable and semiquantitative method for estimating cerebral hemodynamics is PWI. The ability of PWI to assess CBF and metabolism is comparable to that of positron emission tomography. In our study, no significant difference in pre- and postoperative values of these parameters was observed. These results likely reflect the ability of OPCABG to improve neurological outcomes by avoiding hemodynamic, inflammatory, and microembolic perturbations associated with cardiopulmonary bypass [29].

Our study had several limitations. As was mentioned, the sampling examined was relatively small, and the timing of postoperative assessment ( 8 days after surgery) was pragmatic, based on the timing of patient discharge. Cognitive assessments performed at a greater interval after surgery may be more clinically relevant.

Our findings can be summarized in the following way. About $4 \%$ of the patients examined who underwent OPCABG had a perioperative stroke, but no patient showed cognitive decline. These findings are consistent with the absence of changes detected by PWI. Intracranial artery disease and prior cerebral infarction may not be independent risk factors for stroke after OPCABG. However, further studies are required to better understand the predictive values of these conditions for postoperative stroke. 
Acknowledgements This study was supported by the Beijing Medicine Research and Development Fund (grant no.20092075) and the Beijing Science and Technology Project (grant No. Z111107058811013).

The institutional review board approval and a waiver of individual consent requirements were obtained for this study.

The authors, Q. Bi, J.-Yu Li, X.-Q. Li, Q. Li, D. Luo, and Q.-B. Qiao, declare that they have no competing interests.

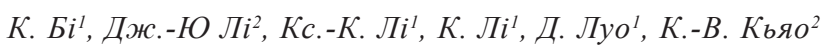

\section{ВПЛИВ СТЕНОЗУ КРАНІАЛЬНИХ АРТЕРІЙ ТА} ПОПЕРЕДНЬОГО ЦЕРЕБРАЛЬНОГО ІНСУЛЬТУ НА УСКЛАДНЕННЯ В ЦНС ПІСЛЯ ШУНТУВАННЯ КОРОНАРНОЇ АРТЕРІЇ БЕЗ ЗАСТОСУВАННЯ ШТУЧНОГО КРОВООБІГУ

\author{
${ }^{1}$ Столичний медичний університет, Пекін (Китай). \\ 2 Пекінський інститут хвороб серця, легень та кровонос- \\ них судин, Пекін (Китай). \\ Р е $з$ ю м е
}

Ми намагалися встановити, чи залежать післяопераційні ускладнення в ЦНС після шунтування коронарної артерії без застосування штучного кровообігу від наявності в попередній період церебрального геморагічного інсульту або стенозу краніальних артерій. 55 пацієнтів (40 чоловіків і 15 жінок, середній вік $64.59 \pm 8.86$ року), котрим була призначена вказана операція, були за добу перед нею піддані неврологічному та нейропсихологічному обстеженню. Магніторезонансне сканування (MRI) було використане для ідентифікації старих та/або нових ішемічних уражень, а магніторезонансна ангіографія (MRA) застосовувалася для встановлення наявності та ступеню стенозу краніальних артерій. Пацієнти були повторно обстежені через вісім діб після операції для виявлення можливих ускладнень (розвитку інсульту або когнітивної дисфункції). Зв'язки між розвитком постопераційного інсульту та можливими предикторами (попереднім інсультом та стенозом краніальних артерій) були проаналізовані із застосуванням методів варіаційної статистики. Післяопераційний інсульт розвився у двох із 55 пацієнтів (3.64\%); зниження рівня когнітивної активності не спостерігалося в жодному випадку. Аналіз не показав вірогідного зв'язку між розвитком післяопераційного інсульту та наявністю попереднього геморагічного інсульту (дані MRI; $P=0.378$ ) або стенозу краніальних артерій (дані MRA; $P=0.103$ ). Наші результати дозволяють вважати, що стеноз краніальних артерій та попередній інсульт не $\epsilon$ незалежними факторами ризику щодо інсульту після шунтування коронарної артерії, але подальші дослідження можливості таких зв'язків є необхідними.

\section{REFERENCES}

1. C. Mérie, L. Køber, P. S. Olsen, et al., "Risk of stroke after coronary artery bypass grafting: effect of age and comorbidities," Stroke, 43, 38-43 (2012).

2. S. Miyazaki, K. Yoshitani, and N. Miura, "Risk factors of stroke and delirium after off-pump coronary artery bypass surgery. Interact," Cardiovascul. Thorac. Surg., 12, 379-383 (2011)

3. M. F. Newman, J. L. Kirchner, B. Phillips-Bute, et al., "Longitudinal assessment of neurocognitive function after coronary-artery bypass surgery," New Engl. J. Med., 344, 395402 (2001).

4. A. E. V. Harten, T. W. L. Scheeren, and A. R. Absalom, "A review of postoperative cognitive dysfunction and neuroinflammation associated with cardiac surgery and anaesthesia," Anaesthesia, 66, 280-293 (2012).

5. L. J. Dacey, D. S. Likosky, B. J. Leavitt, et al., "Perioperative stroke and long-term survival after coronary artery bypass graft," Ann. Thorac. Surg., 79, 532-536 (2005).

6. J. D. Puskas, A. D. Winston, C. E. Wright, et al., "Stroke after coronary artery operation, incidence, correlates, outcome, and cost," Ann. Thorac. Surg., 69, 1053-1056 (2000).

7. L. Cao, Q. Li, Q. Bi, and Q. J. Yu, "Risk factors for recurrent stroke after coronary artery bypass grafting," J. Cardiothorac. Surg., 6, 157-161 (2011).

8. A. C. Anyanwu, F. Filsoufi, S. P. Salzberg, et al., "Epidemiology of stroke after cardiac surgery in the current era," J. Thorac. Cardiovascul. Surg., 134, 1121-1127 (2007).

9. M. Abbaszadeh, "The impact of carotid artery disease on outcomes of patients undergoing coronary artery bypass grafting," Rev. Bras. Circ. Cardiovascul., 26, 258-263 (2011).

10. B. W. Yoon, H. J. Bae, D. W. Kang, et al., "Intracranial cerebral artery disease as a risk factor for central nervous system complications of coronary artery bypass graft surgery," Stroke, 32, 94-99(2001).

11. D. C. Likosky, B. J. Leavitt, C. A. S. Marrin, et al., "Intraand postoperative predictors of stroke after coronary artery bypass grafting," Ann. Thorac. Surg., 76, 428-434 (2003).

12. S. C. Stamou, P. C. Hill, G. Dangas, et al., "Stroke after coronary artery bypass: incidence, predictors, and clinical outcome," Stroke, 32, 1508-1513 (2001).

13. D. Russell and N. Bornstein, "Methods of detecting potential causes of vascular cognitive impairment after coronary artery bypass grafting," J. Neurol. Sci., 229/230, 69-73 (2005).

14. K. Nishiyama, M. Horiguchi, S. Shizuta, et al., "Temporal pattern of strokes after on-pump and off-pump coronary artery bypass graft surgery," Ann. Thorac. Surg., 87, 18391845 (2009).

15. M. F. Folstein, S. E. Folstein, and P. R. McHugh, "Mini-Mental State": a practical method for grading the cognitive state of patients for the clinician," J. Psychiat. Res., 12, 189-198 (1975).

16. J. Ferrari, M. Knoflach, S. Kiechl, et al., "Austrian stroke unit registry collaborators. Early clinical worsening in patients with TIA or minor stroke: the Austrian stroke unit registry," Neurology, 74, 136-141 (2010).

17. T. Uehara, M. Tabuchi, T. Hayashi, et al., "Asymptomatic occlusive lesions of carotid and intracranial arteries in 
Japanese patients with ischemic heart disease," Stroke, 27, 393-397 (1996).

18. R. C. Petersen, G. E. Smith, S. C. Waring, et al., "Mild cognitive impairment. Clinical characterization and outcome," Arch. Neurol., 56, 303-308 (1999).

19. K. J. Nan, Y. C. Wei, F. L. Zhou, et al., "Effects of depression on parameters of cell-mediated immunity in patients with digestive tract cancers," World J. Gastroenterol., 10, 268-272 (2004).

20. G. M. McKhann, M. A. Grega, L. M. Borowicz, Jr., et al., "Stroke and encephalopathy after cardiac surgery: an update," Stroke, 37, 562-571 (2006).

21. C. W. Hogue, R. F. Gottesman, and J. Stearns, "Mechanisms of cerebral injury from cardiac surgery," Crit. Care Clin., 24, 8398 (2008).

22. S. C. Stamou, P. C. Hill, G. Dangas, et al., "Stroke after coronary artery bypass: incidence, predictors, and clinical outcome," Stroke, 32, 1508-1513 (2001).

23. S. Manabe, T. Shimokawa, T. Fukui, et al., "Influence of carotid artery stenosis on stroke in patients undergoing offpump coronary artery bypass grafting," Eur. J. Cardiothorac. Surg., 34, 1005-1008 (2008).

24. E. Cheng-Ching, J. Fong, D. Ontaneda, et al., "Intracranial atherosclerosis as a risk factor for ischemic stroke during open heart surgery," J. Stroke Cerebrovascul. Dis., 19, 257-260 (2010).

25. Y. G. Wan, D. Xu, H. J. Wang, et al., "Impact of prior cerebral infarction on in-hospital mortality in patients with acute myocardial infarction," Zhonghua Nei Ke Za Zhi., 50, 747-749 (2011).

26. A. Ito, T. Goto, K. Maekawa, et al., "Postoperative neurological complications and risk factors for pre-existing silent brain infarction in elderly patients undergoing coronary artery bypass grafting," J. Anesth., 26, 405-411 (2012).

27. G. L. Bryson and A. Wyand, "Evidence based clinical update: general anesthesia and the risk of delirium and postoperative cognitive dysfunction," Can. J. Anaesth., 53, 669-667 (2006).

28. K. K. Martin, J. B. Wigginton, V. L. Babikian, et al., "Intraoperative cerebral high-intensity transient signals and postoperative cognitive function: a systematic review," Am. J. Surg., 197, 55-63 (2009).

29. D. C. Cheng, D. Bainbridge, J. E. Martin, and R. J. Novick, "Evidence-based perioperative clinical outcomes research group: Does off-pump coronary artery bypass reduce mortality, morbidity, and resource utilization when compared with conventional coronary artery bypass? A meta-analysis of randomized trials," Anesthesiology, 102, 188-203 (2005). 